
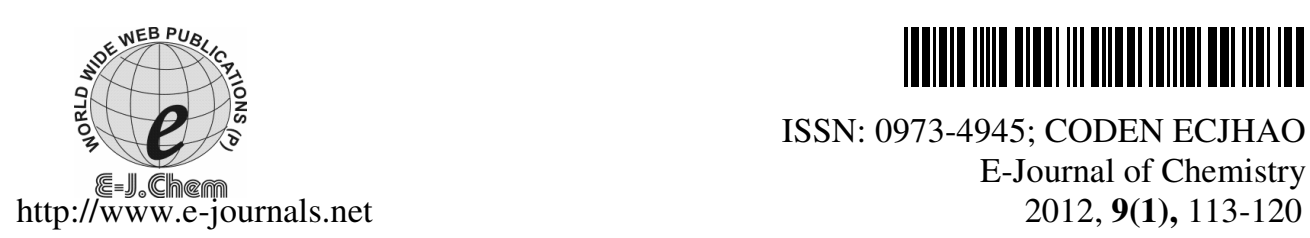

ISSN: 0973-4945; CODEN ECJHAO

E-Journal of Chemistry 2012, 9(1), 113-120

\title{
Synthesis, Isolation and Characterization of Process- Related Impurities in Oseltamivir Phosphate
}

\author{
YOGESH KUMAR* SHARMA, DAU DAYAL AGARWAL, SUDESH BHURE, SANJAY \\ SINGH RATHORE, CHAKRAVIR RAWAT and RAJENDRANATH MUKHARJEE \\ *Department of Industrial Chemistry, Jiwaji University \\ Gwalior-475011, Madhya Pradesh, India \\ Pharmasolve Specialities (I) Pvt. Ltd. Mumbai, India \\ sharma_yogesh9182@rediffmail.com
}

Received 28 May 2011; Accepted 21 July 2011

\begin{abstract}
Three known impurities in oseltamivir phosphate bulk drug at level $0.1 \%$ (ranging from $0.05-0.1 \%$ ) were detected by gradient reverse phase high performance liquid chromatography. These impurities were preliminarily identified by the mass number of the impurities. Different experiments were conducted and finally the known impurities were synthesized and characterized.
\end{abstract}

Keywords: Oseltamivir phosphate, Impurities, Synthesis, Isolation and Characterization

\section{Introduction}

Oseltamivir is an ester prodrug, which is rapidly and extensively hydrolysed in vivo to its active metabolite oseltamivir carboxylate, a potent and selective inhibitor of influenza virus neuraminidase ${ }^{1}$ is considered the leading currently available antiviral to counter a serious epidemic or pandemic outbreak of influenza ${ }^{2,3}$. The current concerns over avian influenza A (H5N1) have created an increased demand for this drug. Pharmaceutical counterfeiting is a well recognized global health problem with a particular impact in developing countries where drug-regulatory systems are weak or ineffective ${ }^{4}$. There have been many alarming reports lasting recent years of counterfeit antimalarials, antibiotics, hormones and steroids, analgesics and antipyretics, anti-asthma and anti-allergy drugs ${ }^{5-11}$.

Oseltamivir phosphate is a white crystalline solid with the chemical name (3R,4R,5S)4-acetylamino-5-amino-3(1-ethylpropoxy)-1-cyclohexene-1-carboxylic acid, ethyl ester, phosphate (1:1). The chemical formula is $\mathrm{C}_{16} \mathrm{H}_{28} \mathrm{~N}_{2} \mathrm{O}_{4}$ (free base). The molecular weight of oseltamivir is 312.4 and 410.4 for oseltamivir phosphate salt ${ }^{12}$. The structural formula is as follows: 
<smiles>CCOC(=O)C1=C[C@@H](OC(CC)CC)[C@H](NC(C)=O)[C@H](N)C1</smiles>

There are several process impurities/related substances associated with the manufacture of oseltamivir phosphate. Different process related impurities have been observed with various synthetic routes and/or manufacturing processes. Six of the known oseltamivir phosphate related substances have been mentioned in International Pharmacopoeia. All these impurities are never present together while we are preparing bulk drug or preparing formulation.

The International Pharmacopoeia ${ }^{12}$ specifies that individual impurity is not more than $0.1 \%$ and total impurity is not more than $0.7 \%$. During the process development of oseltamivir phosphate three known impurities were identified in the analysis of different batches whose percent area ranged from $0.05-0.1 \%$ by HPLC ${ }^{12}$. A comprehensive study has been carried out to isolate or to prepare and characterize these impurities. To the best of our knowledge, synthesis rout of impurities is novel and not reported in literature. Due to the importance of regulatory authorities ${ }^{13}$ all the impurities which are at the level of $>0.1 \%$ must be identified and characterized.

A literature search revealed that only analytical procedure ${ }^{14-18}$ is available but nobody has reported synthesis, isolation and characterization of impurities in the purified form starting from oseltamivir phosphate. The present communication involves the isolation or preparation of impurities and characterization by chromatographic and spectroscopic techniques ${ }^{19}$.

\section{Experimental}

The investigated samples of bulk oseltamivir phosphate were received from pharmasolve specialities (I) Pvt. Ltd. Mumbai.

\section{High performance liquid chromatography (HPLC)}

An LC method was used for monitoring the reaction of oseltamivir impurities. A shimadzu model LC2010CHT equipped with a UV detector was used. The chromatographic conditions optimized were ODS, $50 \times 4.6 \mathrm{~mm}, 3 \mu$ column with a mobile phase -A consisting 900:100(v/v) of $0.05 \mathrm{M} \mathrm{KH} \mathrm{KH}_{2} \mathrm{PO}_{4}$ buffer $\mathrm{pH} 6.0$ and acetonitrile and mobile phase- $\mathrm{B}$ consisting 100:900(v/v) of $0.05 \mathrm{M} \mathrm{KH}_{2} \mathrm{PO}_{4}$ buffer $\mathrm{pH} 6.0$ and acetonitrile with a timed gradient programme of T/\% B:0/20,3/50, 8/100, 15/100, 16/20, 20/20. Detection was carried out at $220 \mathrm{~nm}$ and the flow rate $1.5 \mathrm{~mL} / \mathrm{min}$. Data was recorded by using LC solutions software.

\section{High performance liquid chromatography (preparative)}

An inhouse LC method was developed for the isolation of oseltamivir impurities. A waters LC controller equipped with a UV detector was used. The Prep-HPLC method uses a C18 column (YMC Pack Pro.C-18,250 mm* 20 mmi.d., 10 um particle size) with a mobile phase A consisting of $0.02 \mathrm{M}$ ammonium acetate and mobile phase $\mathrm{B}$ consisting acetonitrile timed gradient programme of T/\% B: 0/0,5/0,8/80, 15/80, 16/0, 20/0. Detection was carried out at $207 \mathrm{~nm}$ and the flow rate was $15.0 \mathrm{~mL} / \mathrm{min}$. Data was recorded by using Empower software. 


\section{Mass spectrometry}

Electrospray ionization mass spectroscopy was performed using an ion trap mass spectrometer (Model 6310 agilent). The positive and negative electrospray MS data was obtained by switching the capillary voltage between $n+5000$ and $-4500 \mathrm{~V}$ respectively.

NMR spectroscopy

The NMR experiments were performed on Bruker avance II $400 \mathrm{MHz}$. The $1 \mathrm{H}$ chemical shift values were reported on the $\delta$ scale in ppm, relative to TMS $(\delta=0.00)$ and the ${ }^{13} \mathrm{C}$ chemical shift values were reported relative to $\mathrm{CDCl}_{3}(\delta=77.00 \mathrm{ppm})$ and DMSO, d6 $(\delta=39.50 \mathrm{ppm})$ as internal standards. ${ }^{1} \mathrm{H}$ and ${ }^{13} \mathrm{C}$ experiment was run using a mixing time of $1000 \mathrm{~ns}$.

\section{FT-IR spectroscopy}

The IR spectra were recorded in the solid state as $\mathrm{KBr}$ dispersion medium using Perkin Elmer spectrum 100 FT-IR spectrophotometer.

\section{Synthesis of impurities}

\section{Synthesis if impurity 1 and 2}

Oseltamivir base $(1 \mathrm{~g})$ was charged with $100 \mathrm{~mL}$ methanol into a double necked round bottom flask with magnetic stirrer. Methanolic sodium hydroxide was added drop wise and the reaction mass was heated very carefully and the reaction mass was refluxed at methanol boiling point. The reaction was monitored after every $1 \mathrm{~h}$ by HPLC. After completion of reaction the reaction mass was neutralised with dilute $\mathrm{HCl}$. The HPLC analysis shown 2 peaks separately which confirm the presence of two different impurities. Both peaks were purified using preparative HPLC and marked as fraction-1 and 2 (Scheme 1). The salt was removed by preparative HPLC after desalting and the sample was kept for freeze drying.<smiles>CCOC(=O)C1=C[C@H](OC(CC)CC)C(NC(C)=O)[C@H](N)C1</smiles>

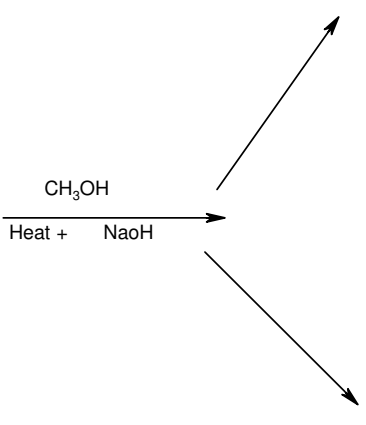

Scheme 1. Synthesis if impurity 1 and $\mathbf{2}$<smiles>CCC(CC)O[C@H]1CC(C(=O)O)=C[C@H](NC(C)=O)C1N</smiles>

Impurity-1(A)<smiles>CCC(CC)O[C@H]1C=C(C(=O)O)C[C@H](N)[C@H]1NC(C)=O</smiles>

Impurity-2(B) 


\section{Synthesis of impurity 3}

Oseltaivir base $(1 \mathrm{~g})$ was charged with $100 \mathrm{~mL}$ methanol into a double necked round bottom flask with megnatic stirrer. To this methanolic sodium hydroxide was added and the reaction mass was stirred at room temperature. The reaction was monitored after every $1 \mathrm{~h}$ by HPLC. The HPLC analysis had shown 1 peak which confirms the presence of one different impurity. This peak was purified using preparative HPLC and marked as fraction-3 (Scheme 2). After completion of reaction the reaction mass was neutralised with dilute $\mathrm{HCl}$. The salt was removed by preprative HPLC after desalting the sample was kept for freeze drying.<smiles>CCOC(=O)C1=C[C@H](OC(CC)CC)[C@H](NC(C)=O)[C@H](N)C1</smiles><smiles>CCC(CC)O[C@H]1C=C(C(=O)OC)C[C@H](N)[C@H]1NC(C)=O</smiles>

Scheme 2. Synthesis if impurity 3

\section{Results and Discussion}

Structure elucidation of impurity 1(Impurity-A)

Sample was analyzed by HPLC and its purity was found to be $94.13 \%$, molecular weight of oseltamivir phosphate impurity-A is $284.36,28$ mass unit less than that of oseltamivir phosphate. The ESI mass spectrum of sample gave a protonated molecular ion at $m / z, 285.1$, which is the same as oseltamivir phosphate impurity-A, IR spectrum displayed characteristic absorptions at $3430.01 \& 2968.79,2939.87 \mathrm{~cm}^{-1}$ corresponding to $>\mathrm{NH}$ and aliphatic $>\mathrm{CH}$ stretching. The peaks at $1642.69 \& 1200.32 \mathrm{~cm}^{-1}$ in IR spectrum are indicative of $>\mathrm{C}=\mathrm{O}$ stretching \& O-C stretching, ${ }^{1} \mathrm{H}$ signals showed the absence of signals at 4.11-4.19 \& 1.20-1.24 ppm was observed as multiplet \& triplet, which could be attributed to a ethyl group absent in impurity-A, but a significant change observed in the position of $1 \mathrm{C} \& 5 \mathrm{C}$ protons which is due to change double bond position in impurity- $\mathrm{A},{ }^{13} \mathrm{C}$ signals showed absence of signals at $60.52 \& 14.02 \mathrm{ppm}$, which could be attributed to a ethyl group absent in impurity-A, but a significant change observed in the position of $1 \mathrm{C} \& 5 \mathrm{C}$ carbons which is due to change double bond position in impurity-A. HPLC purity $94.13 \%$, mass +ve $\mathrm{m} / \mathrm{z}$ 285.1 (Table 1), IR (KBr): 3430.01, 2968.79,2939.87, $1642.69 \& 1200.32$ (Table 1); ${ }^{1} \mathrm{H}$ NMR: $2.03-2.69(\mathrm{dd}, 2 \mathrm{H}), 3.30(\mathrm{~s}, 1 \mathrm{H}), 3.54-3.56(\mathrm{~d}, 1 \mathrm{H}), 3.95\left(\mathrm{~m}^{*}, 1 \mathrm{H}\right), 6.30(\mathrm{~s}, 1 \mathrm{H}), 8.11$ (s, 1H), $1.84(\mathrm{~s}, 3 \mathrm{H}), 2.91(\mathrm{~s}, 1 \mathrm{H}), 1.39(\mathrm{~s}, 4 \mathrm{H}), 0.78-0.83(\mathrm{~d}, 6 \mathrm{H})\left(\right.$ Scheme 3, Table 2); ${ }^{13} \mathrm{C}$ NMR: 32.72, 75.85, 55.55, 49.70, 134.94, 131.19, 169.97, 23.09, 80.58, 25.11, 25.74, 8.91, 9.46 (Scheme 4, Table 3).

\section{Structure elucidation of impurity 2(Impurity-B)}

Sample was analyzed by HPLC and its purity was found to be $92.61 \%$, molecular weight of oseltamivir phosphate impurity-B is $284.36,28$ mass unit less than that of oseltamivir phosphate. The ESI mass spectrum of sample gave a protonated molecular ion at $m / z, 285.0$, which is the same as oseltamivir phosphate impurity-B, IR spectrum displayed characteristic absorptions at $3419.69 \& 2967.75,2939.35 \mathrm{~cm}^{-1}$ corresponding to $>\mathrm{NH}$ and aliphatic $>\mathrm{CH}$ 
stretching. The peaks at $1646.68 \& 1200.14 \mathrm{~cm}^{-1}$ in IR spectrum are indicative of $>\mathrm{C}=\mathrm{O}$ stretching \& O-C stretching, ${ }^{1} \mathrm{H}$ signals showed the absence of signals at 4.11-4.19 \& 1.20-1.24 ppm was observed as multiplet \& triplet, which could be attributed to a ethyl group absent in Impurity-B, ${ }^{13} \mathrm{C}$ signals showed absence of signals at $60.52 \& 14.02 \mathrm{ppm}$, which could be attributed to a ethyl group absent in Impurity-B. HPLC purity $92.61 \%$, mass +ve $\mathrm{m} / \mathrm{z}$ 285.0 (Table 1), IR (KBr): 3419.69, 2967.75,2939.35, 1646.68 \& 1200.14 (Table 1); ${ }^{1} \mathrm{H}$ NMR: $6.19(\mathrm{~s}, 1 \mathrm{H}), 3.38(\mathrm{~s}, 1 \mathrm{H}), 3.83-3.85(\mathrm{~d}, 1 \mathrm{H}), 3.34-3.36(\mathrm{~m}, 1 \mathrm{H}), 2.53-2.60(\mathrm{dd}, 2 \mathrm{H}), 1.83$ $(\mathrm{s}, 3 \mathrm{H}), 3.26-3.29(\mathrm{~m}, 1 \mathrm{H}), 1.33-1.42(\mathrm{~m}, 4 \mathrm{H}), 0.76-0.85(\mathrm{~m}, 6 \mathrm{H})$ (Scheme 3, Table 2); ${ }^{13} \mathrm{C}$ NMR: 137.41, 76.46, 57.97, 50.35, 35.38, 129.20, 169.49, 170.98, 22.99, 80.26, 25.19, 25.82, 8.97, 9.51 (Scheme 4, Table 3).

Table 1. IR and mass spectral data of impurities $1,2 \& 3$

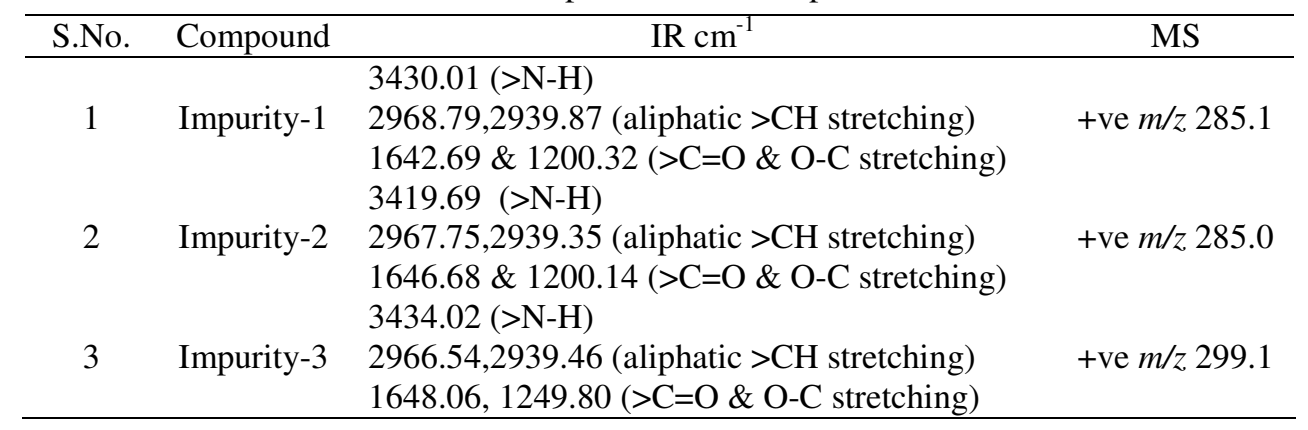

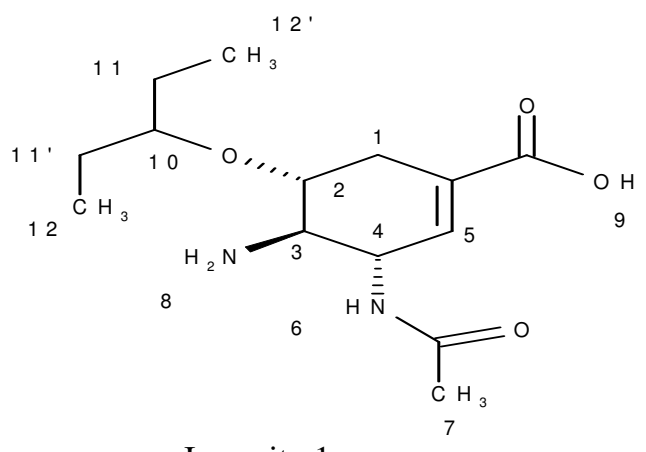

Impurity 1<smiles>CCC(CC)O[C@H]1C=C(C(=O)O)C[C@H](N)[C@H]1NC(C)=O</smiles>

Impurity 2<smiles>CCC(=O)N[C@@H]1[C@@H](N)CC(C(=O)OC)=C[C@@H]1OC(CC)CC</smiles>

Scheme 3. ${ }^{1} \mathrm{H}$ NMR assignment of impurities 1,2 \& 3 


\section{Structure elucidation of impurity 3(Impurity-D)}

Sample was analyzed by HPLC and its purity was found to be $97.37 \%$, molecular weight of oseltamivir phosphate impurity-D is $298.39,14$ mass unit less than that of oseltamivir phosphate. The ESI mass spectrum of sample gave a protonated molecular ion at $\mathrm{m} / \mathrm{z}$ 299.1, which is the same as oseltamivir phosphate impurity-D, IR spectrum displayed characteristic absorptions at $3434.02 \& 2966.54,2939.46 \mathrm{~cm}^{-1}$ corresponding to $>\mathrm{NH}$ and aliphatic $>\mathrm{CH}$ stretching. The peaks at $1648.06 \& 1249.80 \mathrm{~cm}^{-1}$ in IR spectrum are indicative of $>\mathrm{C}=\mathrm{O}$ stretching \& $\mathrm{O}-\mathrm{C}$ stretching, ${ }^{1} \mathrm{H}$ signals showed the absence of signals at 4.11-4.19 \& 1.20-1.24 ppm was observed as multiplet \& triplet, which could be attributed to a ethyl group absent in impurity-D, but an singlet observed at $3.70 \mathrm{ppm}$ which could be attributed to a methoxy group present in Impurity-D, ${ }^{13} \mathrm{C}$ signals showed absence of signals at $60.52 \& 14.02 \mathrm{ppm}$, which could be attributed to a ethyl group absent in Impurity-D, there was a new ${ }^{13} \mathrm{C}$ signal at $48.95 \mathrm{ppm}$ was observed which could be attributed to a methoxy group present in impurity-D. HPLC purity $97.37 \%$, mass +ve $\mathrm{m} / \mathrm{z} 299.1$ (Table 1), IR (KBr): 3434.02, 2966.54,2939.46, 1648.06, 1249.80 (Table 1); ${ }^{1} \mathrm{H}$ NMR: $6.65(\mathrm{~s}, 1 \mathrm{H}), 3.63-3.68(\mathrm{~m}, 1 \mathrm{H}), 4.15-4.17(\mathrm{~m}, 1 \mathrm{H}), 3.37-3.40(\mathrm{~m}, 1 \mathrm{H}), 2.21-2.78$ $(\mathrm{dd}, 2 \mathrm{H}), 8.16-8.18(\mathrm{~d}, 1 \mathrm{H}), 1.87(\mathrm{~s}, 3 \mathrm{H}), 5.49(\mathrm{~b}, 2 \mathrm{H}), 3.70(\mathrm{~s}, 3 \mathrm{H}), 3.09-3.16(\mathrm{~m}, 1 \mathrm{H})$, 1.34-1.48 (m, 4H), 0.76-0.85 (m, 6H) (Scheme 3, Table 2); ${ }^{13} \mathrm{C}$ NMR: $138.60,74.37$, $53.74,51.97,29.87,127.35,170.28,165.80,23.19,81.01,24.97,25.58,8.88,9.42,48.95$ (Scheme 4, Table 3).

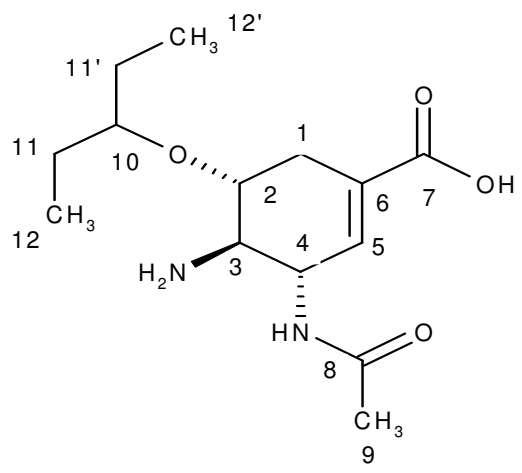

Impurity 1

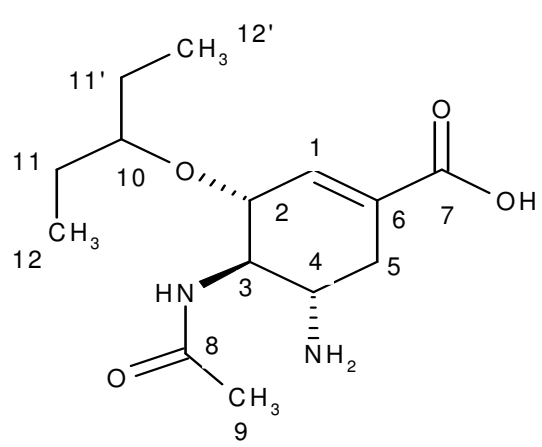

Impurity 2<smiles>CCC(CC)O[C@H]1C=C(C(=O)OC)C[C@H](N)[C@H]1NC(C)=O</smiles>

Impurity 3

Scheme 4. ${ }^{13} \mathrm{C}$ NMR assignment of impurities 1,2 \& 3 
Table 2. ${ }^{1} \mathrm{H}$ NMR spectral data of impurities $1,2 \& 3$

\begin{tabular}{ccccccc}
\hline \multirow{2}{*}{ S.No. } & \multicolumn{2}{c}{ Impurity 1} & \multicolumn{2}{c}{ Impurity 2} & \multicolumn{2}{c}{ Impurity 3} \\
\cline { 2 - 6 } & $\delta, \mathrm{ppm}$ & $\mathrm{H}$ & $\delta, \mathrm{ppm}$ & $\mathrm{H}$ & $\delta, \mathrm{ppm}$ & $\mathrm{H}$ \\
\hline 1 & $2.03-2.69$ & $2 \mathrm{H}$ & 6.19 & $1 \mathrm{H}$ & 6.65 & $1 \mathrm{H}$ \\
2 & 3.30 & $1 \mathrm{H}$ & 3.38 & $1 \mathrm{H}$ & $3.63-3.68$ & $1 \mathrm{H}$ \\
3 & $3.54-3.56$ & $1 \mathrm{H}$ & $3.83-3.85$ & $1 \mathrm{H}$ & $4.15-4.17$ & $1 \mathrm{H}$ \\
4 & 3.95 & $1 \mathrm{H}$ & $3.34-3.36$ & $1 \mathrm{H}$ & $3.37-3.40$ & $1 \mathrm{H}$ \\
5 & 6.30 & $1 \mathrm{H}$ & $2.53-2.60$ & $2 \mathrm{H}$ & $2.21-2.78$ & $2 \mathrm{H}$ \\
6 & 8.11 & $1 \mathrm{H}$ & & & $8.16-8.18$ & $1 \mathrm{H}$ \\
7 & 1.84 & $3 \mathrm{H}$ & 1.83 & $3 \mathrm{H}$ & 1.87 & $3 \mathrm{H}$ \\
8 & & & & & 5.49 & $2 \mathrm{H}$ \\
9 & & & & & 3.70 & $3 \mathrm{H}$ \\
10 & 2.91 & $1 \mathrm{H}$ & $3.26-3.29$ & $1 \mathrm{H}$ & $3.09-3.16$ & $1 \mathrm{H}$ \\
$11,11^{\prime}$ & 1.39 & $4 \mathrm{H}$ & $1.33-1.42$ & $4 \mathrm{H}$ & $1.34-1.48$ & $4 \mathrm{H}$ \\
$12,11^{\prime}$ & $0.78-0.83$ & $6 \mathrm{H}$ & $0.76-0.85$ & $6 \mathrm{H}$ & $0.76-0.85$ & $6 \mathrm{H}$ \\
\hline
\end{tabular}

Table 3. ${ }^{13} \mathrm{C}$ NMR spectral data of impurities 1,2 \& 3

\begin{tabular}{cccc}
\hline Carbon assignment & Impurity 1 & $\begin{array}{c}\text { Impurity } 2 \\
\delta, \text { in ppm }\end{array}$ & Impurity 3 \\
\hline 1 & 32.72 & 137.41 & 138.60 \\
2 & 75.85 & 76.46 & 74.37 \\
3 & 55.55 & 57.97 & 53.74 \\
4 & 49.70 & 50.35 & 51.97 \\
5 & 134.94 & 35.38 & 29.87 \\
6 & 131.19 & 129.20 & 127.35 \\
7 & 169.97 & 169.49 & 170.28 \\
8 & 169.97 & 170.98 & 165.80 \\
9 & 23.09 & 22.99 & 23.19 \\
10 & 80.58 & 80.26 & 81.01 \\
$1111^{\prime}$ & 25.1125 .74 & 25.1925 .82 & 24.9725 .58 \\
$1212^{\prime}$ & 8.919 .46 & 8.979 .51 & 8.889 .42 \\
13 & & & 48.95 \\
\hline
\end{tabular}

\section{Conclusion}

This research paper describes the synthesis, isolation and structure elucidation of process related impurities in oseltamivir phosphate. The impurities was separated by reverse phase chromatographic technique, further isolated these impurities by semi preparative liquid chromatography. The isolated impurities was characterized using spectroscopic techniques. This isolated impurities was used for mass balance of oseltamivir phosphate technical material. The synthesis of impurities was also discussed in brief.

\section{Acknowledgment}

We are grateful thanks to Mr. R. Ganga Prasad, Praveen Sharma and Mr. Avtar Singh, Shophisticated Analytical Instrumentation Facility, Chandigarh and Punjab University, Chandigarh for spectral analytical data. 


\section{References}

1. Hill G, Cihlar T, Oo C, Ho E S, Prior K, Wiltshire H, Barrett J, Liu B and Ward P, Drug Metab Dispos., 2002, 30(1), 13-19.

2. $\quad$ Mayor S, BMJ, 2006, 332(535), 196.

3. Jefferson T, Demicheli V, Rivetti D, Jones M, Di Pietrantonj C and Rivetti A, Lancet., 2006, 367(9507), 303-313.

4. Cockburn R, Newton P N, Agyarko E K, Akunyili D and White N, J PLoS Med., 2005, 2(4), 100.

5. Aldhous P, Nature, 2005, 434, 132-136.

6. Deisingh A.K, Analyst, 2005, 130, 271-279.

7. Newton P N, Dondorp A, Green M, Mayxay M and White N J, Lancet., 2003, 362, 169.

8. Newton P, Proux S, Green M, Smithuis F, Rozendaal J, Prakongpan S, Chotivanich K, Mayxay M, Looareesuwan S, Farrar J, Nosten F and White N J, Lancet., 2001, 357(9272), 1948-1950.

9. $\quad$ Pincock S, BMJ., 2003, 327, 1126.

10. Dondorp A M, Newton P N, Mayxay M, Van Damme W, Smithuis F M, Yeung S, Petit A, Lynam A J, Johnson A, Hien T T, McGready R, Farrar J J, Looareesuwan S, Day N P, Green M D and White N J, Trop Med Int Health., 2004, 9(12), 1241.

11. Csillag C, Lancet., 1998, 352, 553.

12. International Pharmacopoeia, World health organization, $4^{\text {th }}$ Edition, 2008.

13. International Conference on Harmonization, Draft Revised. Federal Register Q3B (R), 2000, 65(139), 4479.

14. Lindegardh N, Hien T T, Farrar J, Singhasivanon P, White N J and Day N P J, $J$ Pharm Biomed Anal., 2006, 42(4), 430-433.

15. Osato H, Jones I L, Chen A, Christina L and Chai L, Organic Lett., 2010, 12, 60-63.

16. Zutter U, Iding H, Spurr P and Wirz B, J Org Chem., 2008, 73, 4895-4902.

17. United States Pharmacopoeia, 34, NF 29, 2011, 33738.

18. Karpf M and Trussardi R, J Org Chem., 2001, 66(6), 2044-2051.

19. Silverstein $\mathrm{R} M$ and Webster F X, Spectrometric Identification of Organic Compounds. $6^{\text {th }}$ Edition, Wiley India, 20s02. 


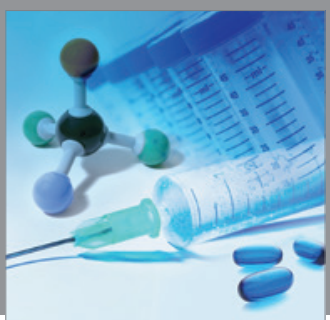

International Journal of

Medicinal Chemistry

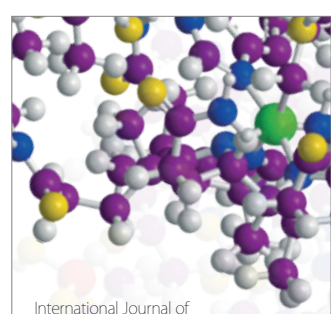

Carbohydrate Chemistry

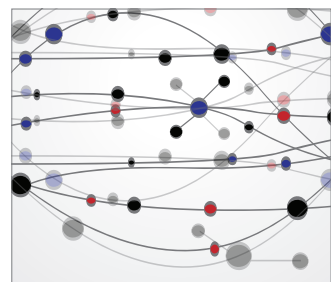

The Scientific World Journal
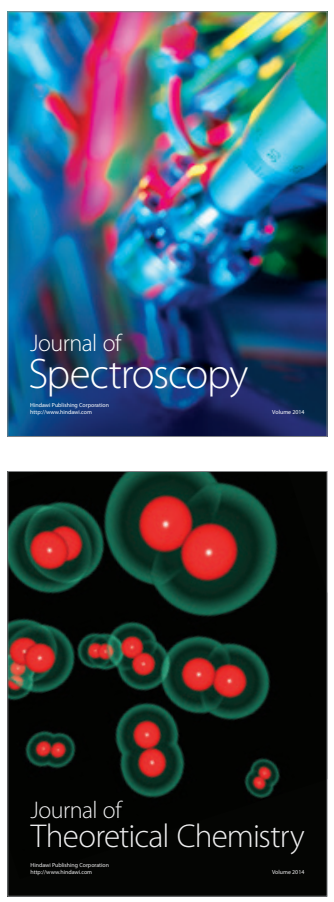
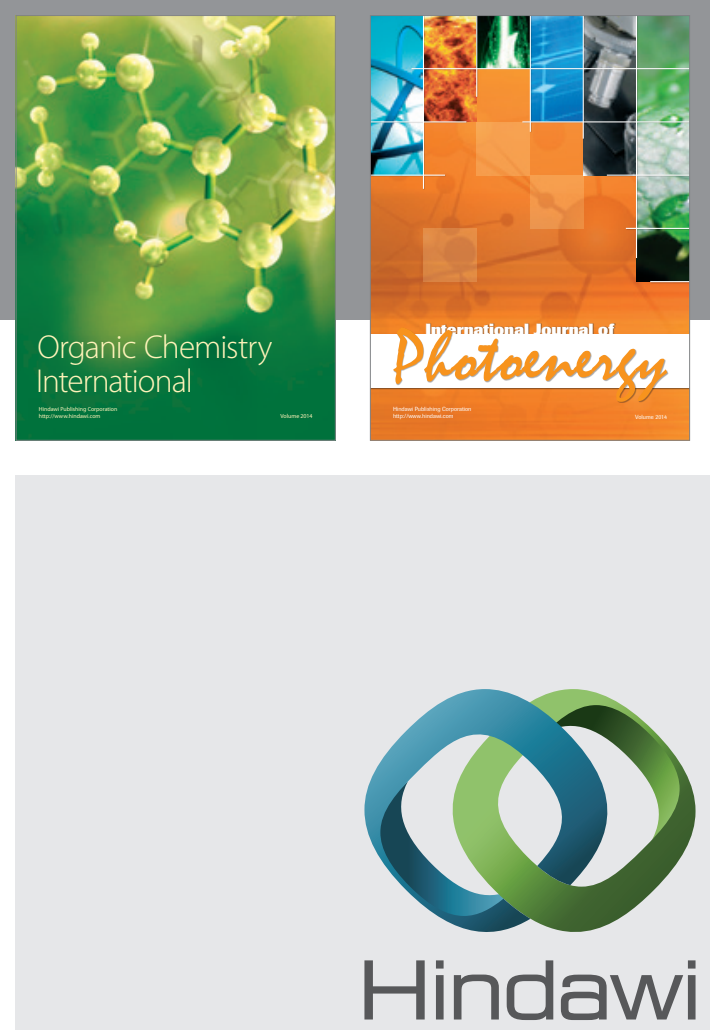

Submit your manuscripts at

http://www.hindawi.com
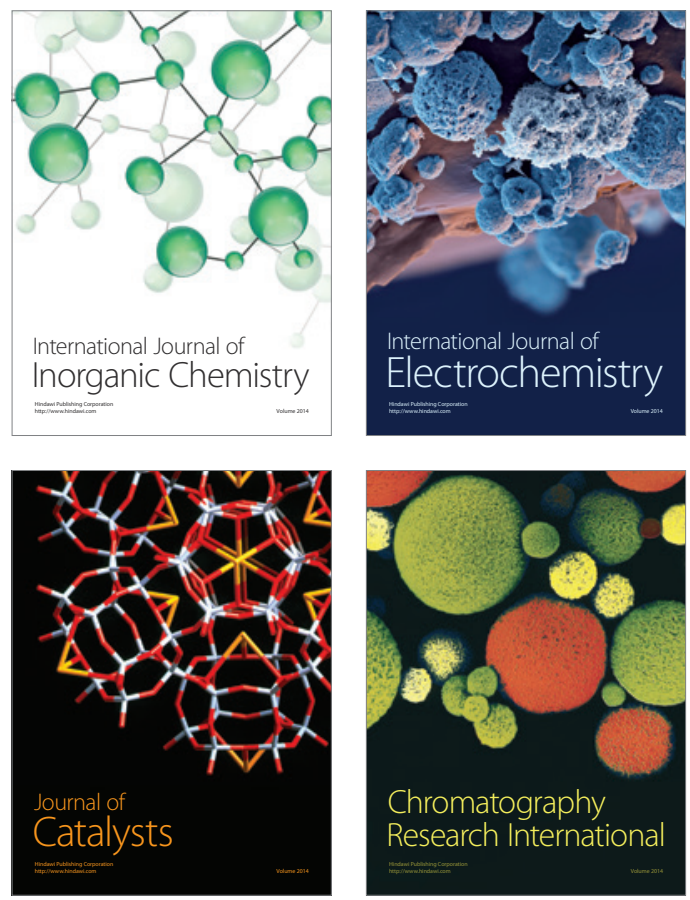
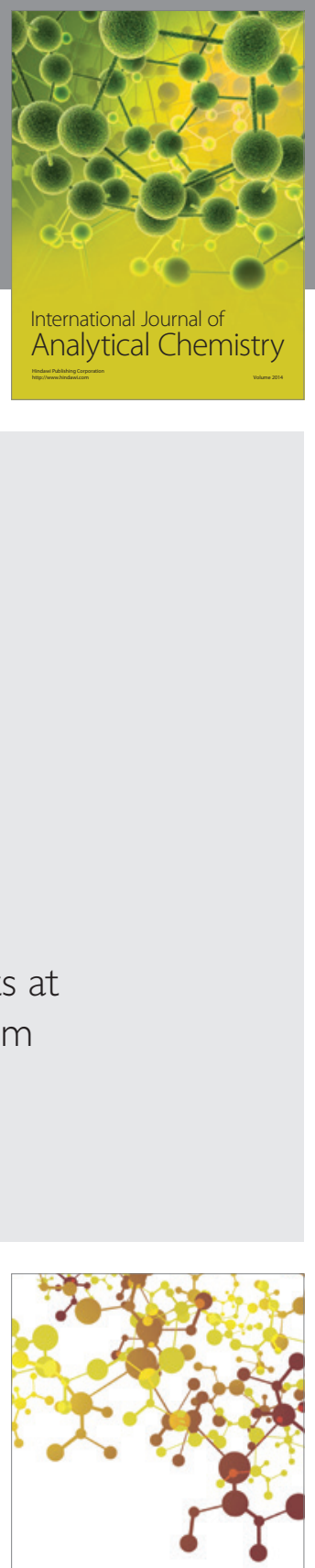

Journal of

Applied Chemistry
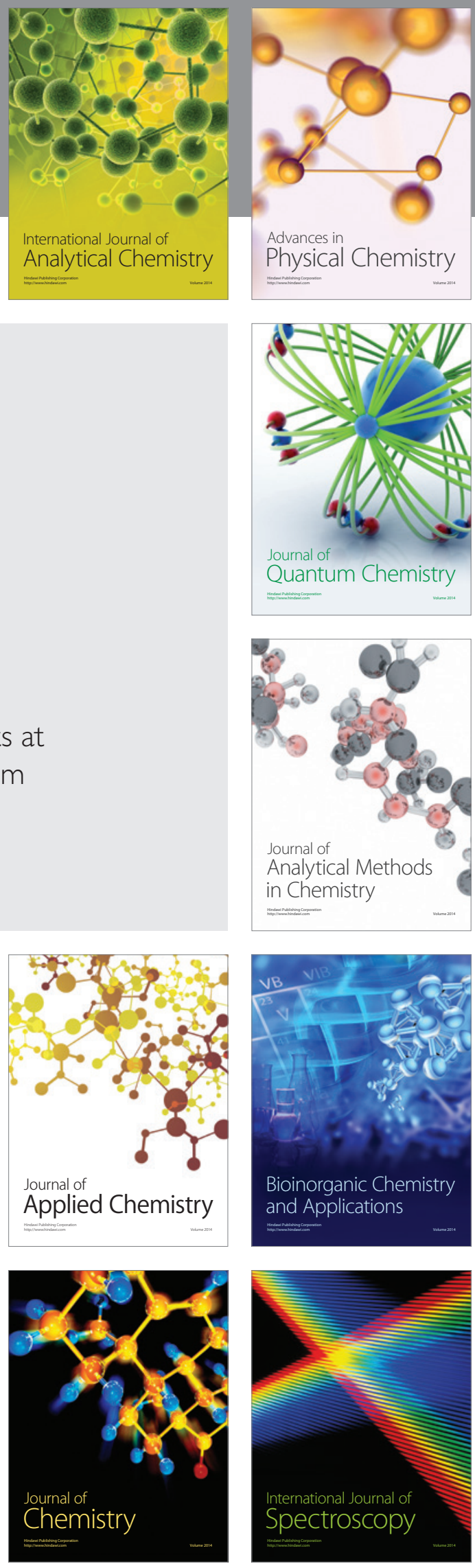